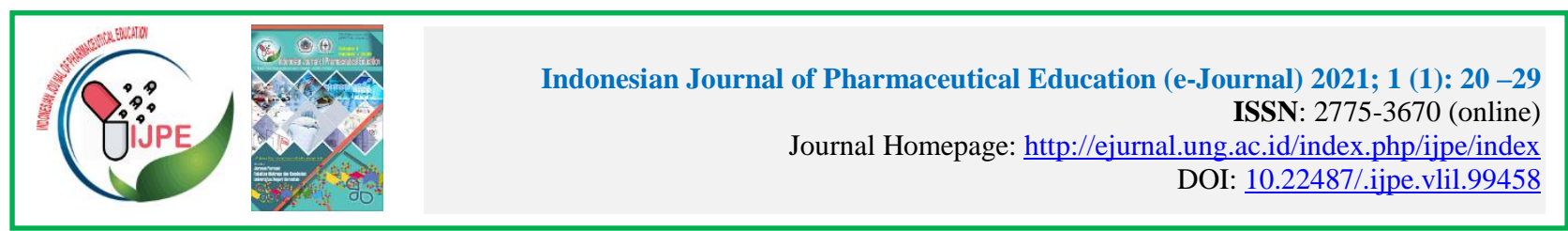

\title{
Hubungan Pengetahuan dan Sikap terhadap Tindakan Pemilihan Obat Untuk Swamedikasi
}

\author{
Madania $^{1 *}$,Mahdalena Sy. Pakaya ${ }^{2}$,Pirdawati Papeo ${ }^{3}$ \\ 1,2,3 Jurusan Farmasi, Fakultas Olahraga dan Kesehatan, Universitas Negeri Gorontalo, Gorontalo \\ *E-mail: madania.tulsyahra@gmail.com \\ Article Info: \\ Received: 15 Desember 2020 \\ in revised form: 20 Januari 2021 \\ Accepted: 28 Januari 2021 \\ Available Online: 23 Februari2021 \\ Keywords: \\ Self-medication \\ Knowledge \\ Tradisional Medicine \\ Modern Medicine \\ Corresponding Author: \\ Madania \\ Jurusan Farmasi \\ Fakultas Olahraga dan Kesehatan \\ Universitas Negeri Gorontalo \\ E-mail: \\ $\underline{\text { madania.tulsyahra@gmail.com }}$

\begin{abstract}
One of the curative efforts often carried out by the community is self-medication. Self-medication is one of the efforts in treating symptoms of illness or illness that is being suffered by someone without consulting a doctor in advance. Selfmedication in its implementation cannot be separated from the use of traditional medicine and modern medicine. This study aimed to measured the correlation between the knowledge and attitude of the people of Tontulow village, North Sulawesi, regarding the tradisional medicine and modern medicine towards their act of selecting the type of medicine for selfmedication. This study was an observational study with a cross sectional design. The sampling technique was performed by cluster sampling method. The instrument of the study was using questionnaire. For normality tes used KlomogrovSmirnov test while for the correlation test used Pearson test. The number of participants were 83 respondents. Most of the people of Tontulow village have a sufficient level of knowledge regarding the traditional medicine and modern medicine, as many as 67 respondents $(80.7 \%)$ with their attitude tended to be positive towards both medicine type. There was a correlation between knowledge and attitude regarding the tradisional medicine and modern medicine towards the act of selecting medicine type (the result of Pearson test: significance value < $0,05)$
\end{abstract}

\section{ब०ब०}

Copyright (C) 2021 IJPE-UNG

This open access article is distributed under a Creative Commons Attribution (CC-BY-NC-SA) 4.0 International license.

How to cite (APA $6^{\text {th }}$ Style):

Madania., Pakaya.M.S.,Papeo.P. (2021). Hubungan Pengetahuan dan Sikap terhadap Tindakan Pemilihan Obat Untuk Swamedikasi.Indonesian Journal of Pharmaceutical (e-Journal), 1(1), 20-29. 


\section{ABSTRAK}

Salah satu upaya kuratif yang sering dilakukan oleh masyarakat adalah swamedikasi atau pengobatan mandiri. Swamedikasi adalah salah satu upaya yang sering dilakukan oleh seseorang dalam mengobati gejala sakit atau penyakit yang sedang dideritanya tanpa terlebih dahulu melakukan konsultasi kepada dokter. Swamedikasi dalam pelaksanaanya tidak lepas dari penggunaan obat tradisional dan obat modern. Penelitian ini bertujuan untuk mengukur hubungan antara pengetahuan dan sikap masyarakat mengenai obat tradisional dan obat modern dengan tindakan pemilihan jenis obat untuk swamedikasi di Desa Tontulow, Provinsi Sulawesi Utara. Penelitian ini merupakan studi observasional dengan desain cross sectional. Teknik pengambilan sampel dilakukan dengan metode cluster sampling. Instrument penelitian ini adalah kuisioner. Untuk uji normalitas menggunakan Klomogrov-Smirnov, sedangkan untuk uji korelasi menggunakan uji korelasi Pearson. Total partisipan adalah 83 responden. Sebagian besar masyarakat desa Tontulow memiliki tingkat pengetahuan yang cukup mengenai obat tradisional dan obat modern sebanyak 67 responden $(80,7 \%)$ dengan sikap yang cenderung positif terhadap obat tradisional dan obat modern. Terdapat hubungan antara pengetahuan dan sikap terhadap tindakan pemilihan obat tradisional dan obat modern (hasil uji korelasi Pearson nilai signifikasi $<0,05$ )

Kata Kunci: Swamedikasi, Pengetahuan, Obat Tradisional, Obat Modern

\section{Pendahuluan}

Kesehatan merupakan keadaan sejahtera dari badan, jiwa, dan sosial yang memungkinkan setiap orang hidup produktif secara sosial dan ekonomis. Upaya kesehatan yang dilakukan oleh pemerintah dan masyarakat dapat dilakukan melalui peningkatan kesehatan (promotif), pencegahan penyakit (kuratif), dan pemulihan kesehatan (rehabilitatif) yang dilaksanakan secara menyeluruh, terpadu dan berkesinambungan [1]

Salah satu upaya kesehatan kuratif yang sering dilakukan oleh masyarakat adalah pengobatan mandiri yang dikenal dengan istilah swamedikasi yang pada pelaksanaannya diatur dalam permenkes No.919/MENKES/PER/X/1993. Menurut Pratiwi et al [2] menyatakan swamedikasi merupakan salah satu upaya yang sering dilakukan oleh seseorang dalam mengobati gejala sakit atau penyakit yang sedang dideritanya tanpa terlebih dahulu melakukan konsultasi kepada dokter.

Menurut Penelitian Kartajaya [3] Persentase pengobatan sendiri di Amerika Serikat mencapai 73\%. Angka ini bahkan cenderung meningkat karenaterdapat enam dari sepuluh orang di Amerika yang mengatakan bahwamereka mungkin akan melakukan pengobatan sendiri lagi di masa yangakan datang terhadap penyakit yang dideritanya.Hasil survey sosial ekonomi nasional (Susenas) tahun 2014 menunjukkan bahwa presentase penduduk indonesia yang melakukan swamedikasi atau pengobatan diri sendiri akibat keluhan kesehatan yang dialami sebesar $61,05 \%$. Hal ini menunjukkan bahwa perilaku swamedikasi di Indonesia masih cukup besar [4].

Tingginya persentasi swamedikasi dapat menjadi salah satu penyebab munculnya kesalahan pengobatan. Hal tersebut dibuktikan dengan penelitian oleh Ikatan Apoteker Indonesia pada tahun 2014 tentang penggunaan obat, yang menyatakan bahwa berbagai masalah kesehatan masih banyak terjadi, khususnya terkait obat masih ditemui dimasyarakat. Mulai dari penggunaan salah obat, penyalahgunaan obat, terjadinya efek samping obat dari yang paling ringan sampai dengan kebutaan dan kematian, beredarnya obat palsu, narkoba dan bahan berbahaya lainnya yang sebagian besar diakibatkan oleh perilaku swamedikasi. Hal ini menyebabkan belum tercapainya derajat kesehatan yang setinggi-tingginya sebagaimana tertuang dalam undang-undang Nomor 36 Tahun 2009. 
Dalam pelaksanaannya, swamedikasi tentunya tidak lepas dari penggunaan obat modern dan obat tradisional. Obat tradisional adalah obat-obatan yang diolah secara tradisional, turun-temurun, berdasarkan resep nenek moyang, adat-istiadat, kepercayaan, atau kebiasaan setempat, baik bersifat magic maupun pengetahuan tradisional yang umumnya menggunakan bahan dasar yang bersifat alamiah. Terdapat tiga jenis obat tradisional, yaitu jamu, fitofarmaka, dan Obat Herbal Terstandar (OHT). Sedangkan, obat modern adalah obat yang biasa diproduksi secara modern dengan penambahan bahan kimia. Terdapat tiga jenis obat modern yang dapat digunakan untuk swamedikasi, yaitu obat bebas, obat bebas terbatas, dan obat keras daftar OWA (Obat Wajib Apotek).

Benyamin Bloom, dalam teorinya mengatakan bahwa perilaku manusia dibagi kedalam tiga ranah (kawasan), yaitu kognitif (cognitive), afektif (affectif), dan psikomotor (pcychomotor). Teori tersebut dalam perkembanganya dimodifikasi untuk mengukur hasil pendidikan kesehatan menjadi pengetahuan, sikap, dan tindakan. Pengetahuan dan sikap merupakan dua faktor penting yang dapat mempengaruhi tindakan pemilihan obat (obat tradisional atau obat modern) untuk swamedikasi ([5] [6]).

Notoatmodjo [7]meyatakan bahwa pengetahuan merupakan domain terpenting seseorang untuk menentukan respon batin dalam bentuk sikap yang akan membentuk suatu tindakan (action) sesuai dengan stimulus yang diterima. Ketika masyarakat mendapatkan informasi yang benar mengenai suatu produk obat tradisional maupun obat modern maka akan menambah pengetahuan sehingga mereka mampu menentukan sikap, serta tindakan yang baik dalam melakukan swamedikasi.

Observasi awal yang dilakukan oleh peneliti, mengungkapkan bahwa sebagian besar masyarakat desa Tontulow masih banyak melakukan swamedikasi untuk mengatasi masalah kesehatan. Berdasarkan latar belakang diatas maka peneliti tertarik untuk melihat pola serta alasan swamedikasi yang dilakukan masyarakat, mengukur tingkat pengetahuan masyarakat mengenai obat tradisional dan obat modern, melihat sikap masyarakat terhadap obat tradisional dan obat modern, melihat tindakan pemilihan obat untuk swamedikasi, serta mengukur hubungan pengetahuan, sikap, dan tindakan pemilihan obat untuk swamedikasi.

Penelitian ini diharapkan dapat mengukur tingkat pengetahuan masyarakat, serta mengukur hubungan tingkat pengetahuan dan sikap dengan tindakan pemilihan obat untuk swamedikasi. Hasil penelitian sebelumnya menunjukkan bahwa sebagian besar masyarakat memiliki tingkat pengetahuan yang cukup, sikap serta tindakan yang berpihak kepada obat tradisional, serta terdapat hubungan yang signifikan antara pengetahuan, sikap, dan tindakan pemilihan obat tradisional dan obat modern untuk swamedikasi.

\section{Metode}

Jenis penelitian ini adalah penelitian non eksperimental dengan pendekatan cross sctional. Pada penelitian ini data diambil dari kuisioner yang dibagikan dan diisi oleh responden sebagai data primer. Data Monografi Desa Tontulow sebagai data sekunder. Waktu dan Tempat penelitian dilaksanakan pada bulan Oktober-November 2018 di Desa Tontulow, Provinsi Sulawesi Utara. Populasi dalam penelitian ini adalah seluruh masyarakat desa Tontulow yang berusia lebih atau sama dengan 18 tahun sebanyak 496 individu. Teknik pengambilan sampel dalam penelitian ini menggunakan cluster sampling. Adapun kriteria ekslusi pada penelitian ini adalah masyarakat yang buta aksara, masyarakat yang berprofesi sebagai tenaga kesehatan, dan masyarakat yang sedanga menempuh pendidikan dibidang kesehatan. 
Kuisioner sebagai alat ukur dalam penelitian ini, terlebih dahulu diuji validitas dan reliabilitasnya. Kuisioner tersebut terdiri dari empat bagian. Bagian pertama sebanyak 9 pertanyaan adalah pertanyaan screening untuk melihat pola dan alasan swamedikasi, bagian kedua adalah 23 item pertanyaan dengan skala Guttman untuk mengukur tingkat pengetahuan masyarakat mengenai obat tradisional dan obat modern, dan bagian ke empat adalah 8 peryataan dengan penggunaan skala Likert sebagai skala pengukuran untuk melihat sikap serta tindakan masyarakat terhadap obat tradisional dan obat modern.

Variabel bebas pada penelitian ini adalah pengetahuan masyarakat tentang obat tradisional dan obat modern, serta sikap masyarakat terhadap obat tradisional dan obat modern. Sedangkan, variabel terikat pada penelitian ini adalah tindakan pemilihan obat tradisional dan obat modern. Analisis yang digunakan dalam penelitian ini adalah analisis korelasi Pearson.

\section{Hasil dan Pembahasan}

Masyarakat Desa Tontulow yang berusia lebih atau sama dengan 18 tahun telah menjadi populasi dalam penelitian ini. Besar sampel dalam penelitian ini berjumlah 83 dari total populasi 496 individu. Data bersumber dari buku Data Monografi Desa Tontulow 2018. Berikut adalah distribusi responden berdasarkan karakteristiknya.

Tabel 1. Karakteristik Responden

\begin{tabular}{|c|c|}
\hline Karakteristik & Jumlah (\%) \\
\hline \multicolumn{2}{|l|}{ Jenis Kelamin } \\
\hline Perempuan & $52(62,7 \%)$ \\
\hline Laki-Laki & $31(37,3 \%)$ \\
\hline Total & $83(100 \%)$ \\
\hline \multicolumn{2}{|l|}{ Usia } \\
\hline $18-40$ & $56(67,5 \%)$ \\
\hline $41-60$ & $27(32,5 \%)$ \\
\hline Total & $83(100 \%)$ \\
\hline \multicolumn{2}{|l|}{ Pendidikan Terakhir } \\
\hline SD & $27(32,5 \%)$ \\
\hline SMP & $4(4,8 \%)$ \\
\hline SMA & $26(31,3 \%)$ \\
\hline Perguruan Tinggi & $26(31,3 \%)$ \\
\hline Total & $83(100 \%)$ \\
\hline \multicolumn{2}{|l|}{ Pekerjaan } \\
\hline PNS & $8(9,6 \%)$ \\
\hline IRT & $33(39,8 \%)$ \\
\hline Guru Honorer/ Pegawai Honorer & $8(9,6 \%)$ \\
\hline Petani/ Buruh Tani & $18(21,7 \%)$ \\
\hline Wiraswasta/ Pegawai Swasta & $2(2,4 \%)$ \\
\hline Aparat Desa & $6(7,2 \%)$ \\
\hline Lainnya & $8(9,6 \%)$ \\
\hline Total & $83(100 \%)$ \\
\hline \multicolumn{2}{|l|}{ Pendapatan } \\
\hline$<$ Rp. $500.000,00$ & $29(34,9 \%)$ \\
\hline Rp. $500.000,00$ - Rp. $1.000 .000,00$ & $33(39,8 \%)$ \\
\hline Rp. $1.000 .000,00$ - Rp. $2.000 .000,00$ & $4(4,8 \%)$ \\
\hline > Rp. 2.000.000,00 & $17(20,5 \%)$ \\
\hline
\end{tabular}




Total $83(\mathbf{1 0 0} \%)$

Berdasarkan Tabel 1. didapatkan hasil bahwa mayoritas responden berjenis kelamin perempuan sebanyak 52 orang (62,7\%), dengan mayoritas responden berusia 18-40 tahun 56 orang (67,5\%). Berdasarkan pendidikan terakhir, mayoritas responden berpendidikan tinggi (SMA dan Perguruan Tinggi) sebanyak 52 orang (62,6\%). Berdasarkan pekerjaan mayoritas responden bekerja sebagai Ibu Rumah Tangga (IRT) sebanyak 33 orang $(39,8 \%)$. Untuk pendapatan perbulan mayoritas responden memiliki pendapatan Rp. 500.000,00 - Rp. 1.000.000,00 sebanyak 33 orang (39,8\%).

Arikunto [8] membagi pengetahuan kedalam tiga kategori, yaitu pengetahuan baik bila responden dapat menjawab $76-100 \%$ dengan benar dari total jawaban pertanyaan, cukup bila responden dapat menjawab 56-75\% dengan benar dari total jawaban pertanyaan, kurang bila responden dapat menjawab $<56 \%$ dari total jawaban pertanyaan.

Tabel 2. Tingkat Pengetahuan Responden

\begin{tabular}{cl}
\hline Pengetahuan & Jumlah (\%) \\
\hline Baik & $12(14,5 \%)$ \\
Cukup & $67(80,7 \%)$ \\
Kurang & $5(4,8 \%)$ \\
\hline Total & $\mathbf{8 3 ( 1 0 0 \% )}$
\end{tabular}

Sumber: Data yang diolah 2018

Berdasarkan tabel 2. Didapatkan bahwa hasil penelitian tentang pengetahuan mengenai obat tradisional dan obat modern pada masyarakat di Desa Tontulow, Provinsi Sulawesi Utara, mayoritas responden memiliki tingkat pengetahuan yang cukup, yaitu sebanyak 67 orang $(80,7 \%)$.

Skala likert adalah salah satu skala sikap yang sering digunakan untuk mengukur sikap. Dalam skala likert peryataan pernyataan yang diajukan baik pernyataan positif maupun pernyataan negatif, dinilai oleh subjek dengan setuju, sangat setuju, tidak setuju dan sangat tidak setuju [9]. Perhitungan skala likert didasarkan pada distribusi jawaban responden. Dari hasil penelitian didapatkan skala likert untuk pernyataan positif (+), yaitu sangat setuju (skor akhir 250-332), setuju (skor akhir 167-249), tidak setuju (skor akhir 83-166), sangat tidak setuju (skor akhir 0-82). Adapun skala likert untuk pernyataan negatif (-) yaitu sangat setuju (0-82), setuju (skor akhir 83-166), tidak setuju (skor akhir 167-249), sangat tidak setuju (skor akhir 250-332).

Tabel 3. Distribusi skor akhir sikap responden

\begin{tabular}{clccc}
\hline No. & \multicolumn{1}{c}{ Pernyataan } & $\begin{array}{c}\text { Jenis } \\
\text { pernyataan }\end{array}$ & $\begin{array}{c}\text { Skor } \\
\text { akhir }\end{array}$ & Skala Sikap \\
\hline 1. & $\begin{array}{l}\text { Menggunakan obat tradisional dalam } \\
\text { pengobatan mandiri sangat } \\
\text { bermanfaat. }\end{array}$ & + & 274 & Sangat setuju \\
\hline 2. & $\begin{array}{l}\text { Menggunakan obat tradisional dalam } \\
\text { pengobatan mandiri sangat merugikan. }\end{array}$ & - & 247 & Tidak setuju \\
\hline 3. & $\begin{array}{l}\text { Menggunakan obat modern dalam } \\
\text { pengobatan mandiri sangat } \\
\text { menguntungkan. }\end{array}$ & + & 303 & Sangat setuju \\
& & & \\
\hline
\end{tabular}




4. $\begin{aligned} & \text { Menggunakan obat modern dalam } \\ & \text { pengobatan mandiri sangat } \\ & \text { membahayakan. }\end{aligned}$
.

Berdasarkan tabel 3. Dapat dilihat bahwa skor akhir untuk pertanyaan pertama $(+)$ adalah 274 yang masuk skala sikap sangat setuju. Sedangkan untuk peryataan kedua (-) adalah 247 yang termasuk dalam skala sikap tidak setuju. Adapun untuk pernyataan ketiga (+) adalah 303 dengan skala sikap sangat setuju, dan peryataan terakhir (-) 320 yang masuk skala sangat tidak setuju.

Tabel 4. Distribusi skor akhir tindakan responden

\begin{tabular}{clccc}
\hline No. & \multicolumn{1}{c}{ Pernyataan } & $\begin{array}{c}\text { Jenis } \\
\text { pernyataan }\end{array}$ & $\begin{array}{c}\text { Skor } \\
\text { akhir }\end{array}$ & Skala Sikap \\
\hline 1. & $\begin{array}{l}\text { Saya akan memilih menggunakan obat } \\
\text { tradisional sebagai pengobatan utama } \\
\text { ketika sakit. }\end{array}$ & + & 282 & Sangat setuju \\
\hline 2. & $\begin{array}{l}\text { Jika saya melakukan pengobatan } \\
\text { mandiri, maka saya akan menggunakan } \\
\text { obat tradisional. }\end{array}$ & + & 253 & Sangat setuju \\
\hline 3. & $\begin{array}{l}\text { Saya akan memilih menggunakan obat } \\
\text { modern (obat dengan bahan kimia) } \\
\text { sebagai pengobatan utama ketika sakit. }\end{array}$ & + & 245 & Setuju \\
\hline 4. & $\begin{array}{l}\text { Jika saya melakukan pengobatan } \\
\text { mandiri, maka saya akan menggunakan } \\
\text { obat modern. }\end{array}$ & + & 244 & Setuju \\
\hline
\end{tabular}

Berdasarkan tabel 4. Dapat dilihat bahwa skor akhir untuk pertanyaan pertama $(+)$ adalah 282 yang masuk skala sangat setuju. Sedangkan untuk peryataan kedua $(+)$ adalah 253 yang termasuk dalam skala sangat setuju. Adapun untuk pernyataan ketiga $(+)$ adalah 245 dengan skala setuju, dan peryataan terakhir (+) 244 yang masuk skala setuju.

\begin{tabular}{l} 
Tabel 5. Hasil Uji Korelasi Hubungan Pengetahuan dan Sikap terhadap Tindakan \\
$\begin{array}{cc}\text { Pemilihan Obat Tradisional dan Obat Modern } \\
\text { Variabel }\end{array}$ \\
$\begin{array}{c}\text { Pengetahuan dengan tindakan } \\
\text { pemilihan obat untuk } \\
\text { swamedikasi }\end{array}$ \\
$\begin{array}{c}\text { Sikap dengan tindakan pemilihan } \\
\text { obat untuk swamedikasi }\end{array}$ \\
\hline
\end{tabular}

Berdasarkan Tabel 5. Dapat dilihat bahwa terdapat hubungan yang signifikan antara pengetahuan dan sikap terhadap tindakan pemilihan obat tradisional dan obat modern untuk swamedikasi dengan nilai signifikansi $<0,05$.

\subsection{Karakteristik Responden}

Responden pada penelitian ini adalah masyarakat Desa Tontulow, Provinsi Sulawesi Utara. Berdasarkan karakteristik jenis kelamin menunjukan bahwa mayoritas responden berjenis kelamin perempuan sebanyak 52 (62,7\%). Responden terbanyak 
adalah wanita karena penelitian kebanyakan dilaksanakan pada waktu pagi dan sore hari yang menyebabkan sebagian besar responden yang ditemui adalah ibu rumah tangga. Berdasarkan hasil penelitian yang didapatkan bahwa mayoritas responden berusia 18-40 tahun yaitu sebanyak 56 responden $(67,5 \%)$. Hal ini karena, responden dengan usia muda lebih antusias berpartisipasi dalam penelitian ini. Adapun tingkat pendidikan responden sebagian besar adalah reponden dengan tingkat pendidikan tinggi yaitu SMA dan Perguruan Tinggi, dengan jumlah 52 responden. Responden dengan tingkat pendidikan rendah cenderung merasa tidak mampu sehingga sebagian menolak untuk mengisi kuisioner. Adapun mayoritas pekerjaan adalah ibu rumah tangga dengan jumlah 33 responden $(39,8 \%)$. Tingkat pendapatan masyarakat sebagian besar berada diantara Rp. 500.000,00-Rp. 1.000.000,00 sebanyak 29 responden (34,9\%). Kecenderungan swamedikasi lebih banyak pada masyarakat dengan tingkat pendapatan rendah, hal tersebut menuntut mereka untuk meningkatkan pengetahuan tentang obat tradisional dan obat modern [10].

\subsection{Pengetahuan}

Pengetahuan merupakan hasil tahu yang terjadi setelah seseorang melakukan penginderaan terhadap objek tertentu. Pengideraan terjadi melalui panca indera manusia, yakni indera pengelihatan, pendengaran, penciuman, perasa, dan peraba. Sebagian besar pengetahuan seseorang diperoleh dari mata dan telinga. Dari Pengalaman, seseorang dapat memecahkan permasalahan yang dihadapi sehingga pengetahuan merupakan faktor yang penting dalam tindakan ([10][11]).

Pada penelitian ini pengetahuan masyarakat dilihat dari beberapa indikator tentang obat tradisional dan obat modern yaitu defnisi, bentuk sediaan, dosis, penggolongan, pengenalan logo obat, contoh obat serta indikasinya, aturan pakai, efek samping, kontraindikasi, dan penggunaan obat untuk pengobatan mandiri.

Berdasarkan hasil penelitian pada tabel 2. didapatkan bahwa mayoritas responden memiliki tingkat pengetahuan yang cukup sebanyak 67 responden $(80,7 \%)$. Hal tersebut menunjukkan bahwa responden sudah punya pengetahuan yang cukup, sehingga kemungkinan aplikasi pengetahuan mengenai obat tradisional dan obat modern dalam pengobatan mandiri secara umum dapat diterapkan atau diaplikasikan dengan cukup baik dalam melakukan swamedikasi.

Hasil penelitian menunjukan untuk obat modern didapatkan hasil sebagian masyarakat sudah mengetahui semua indikator tentang obat modern. Sedangkan untuk obat tradisional, masih banyak masyarakat yang belum mengetahui tentang dosis, aturan pakai, serta efek samping obat tradisional. Menurut masyarakat obat tradisional tidak memiliki takaran dosis yang tepat pada penggunaanya dan penggunaan obat tradisional tidak perlu mengikuti aturan pakai yang tertera pada kemasan serta tidak adanya efek samping yang ditimbulkan dari penggunaan obat tradisional.

Hal ini tentunya adalah anggapan yang salah karena obat tradisional harus digunakan sesuai dengan aturan pakai. Depkes RI [12], menyatakan bahwa obat tradisional, khususnya obat herbal terstandar (OHT) dan Fitofarmaka sudah diketahui pasti dosisnya sehingga pada penggunaanya harus memperhatikan aturan pakai, baik dosis maupun waktu penggunaan produk obat tradisional agar tidak menimbulkan efek samping. Hal tersebut menunjukan bahwa masyarakat lebih banyak mengetahui tentang obat modern dari pada obat tradisional.

\section{3..3 Sikap}

Sikap adalah evaluasi atau keinginan untuk memihak (favorable) atau tidak memihak (unfavorabel) terhadap suatu objek tertentu. Sikap juga merupakan kecenderungan bertindak dari individu, berupa respon tertutup terhadap stimulus atau 
objek tertentu. Sikap merupakan kesiapan untuk bereaksi terhadap objek dilingkungan tertentu sebagai suatu penghayatan terhadap objek. Objek disini adalah penggunaan obat tradisional dan obat modern dalam pengobatan mandiri ([13][14]).

Dari hasil pengolahan data dengan menggunakan skala likert didapatkan hasil pada tabel 3. bahwa responden cenderung bersikap setuju atau bersikap positif terhadap obat tradisional dan obat modern. Hal tersebut dapat dilihat pada hasil pengukuran sikap terhadap empat pernyataan dimana, skor akhir dari sikap responden masuk dalam kategori setuju pada pernyataan yang memihak obat tradisional dan obat modern dan juga masuk kategori tidak setuju terhadap pernyataan yang tidak memihak obat tradisional dan obat modern. Hal ini tidak sejalan dengan penelitian yang dilakukan oleh Pangastuti [10], dimana responden sebagian besar bersikap setuju atau bersikap positif pada obat tradisional.

3.4 Tindakan

Tindakan merupakan kemampuan untuk mengaplikasikan apa yang diketahui terhadap stimulus yang diterima. Stimulus disini adalah informasi dan pengetahuan yang mereka miliki tentang pengobatan mandiri, obat tradisional dan obat modern. sedangkan aplikasi atau prakteknya adalah penggunaan obat tradisional dan obat modern tersebut dalam pengobatan mandiri atau swamedikasi yang akan dilakukan ([7][10]).

Dari hasil penelitian pada tabel 4. dapat dilihat bahwa tindakan sebagian besar responden cenderung netral atau memilih keduanya untuk swamedikasi. Hal tersebut dapat dilihat pada kecenderungan bertindak yang setuju terhadap keempat pernyataan tentang pengunaan obat tradisional dan obat modern untuk swamedikasi. Hasil penelitian tersebut tidak sejalan dengan penelitian oleh Pangastuti [10] bahwa sebagian besar responden lebih memilih obat tradisional sebagai pengobatan dari pada obat modern atau keduanya.

\subsection{Hubungan Pengetahuan dan Sikap terhadap Tindakan}

Berdasarkan hasil uji korelasi Pearson pada table 5. dapat dilihat bahwa terdapat hubungan antara pengetahuan dan sikap terhadap tindakan pemilihan obat dengan nilai signifikansi yang dihasilkan sebesar 0,001 pada hubungan antara pengetahuan dan perilaku dan 0,000 pada hubungan sikap dan tindakan pemilihan obat tradisional dan obat modern.

Hasil penelitian ini sejalan dengan penelitian Pangastuti [10],yang menyatakan bahwa terdapat hubungan antara Pengetahuan dan Sikap Terhadap Tindakan pemilihan obat tradisional dan obat modern pada masyarakat Desa Bantir, Kecamatan Candiroto, Yogyakarta. Sebaliknya, hasil penelitian ini tidak sejalan dengan penelitian Cristiana [15] yang menyatakan bahwa tidak terdapat hubungan antara pengetahuan dan sikap terhadap perilaku pemilihan obat tradisional dan obat modern dikalangan mahasiswa.

Pangastuti [10], menyatakan bahwa pada dasarnya, terbentuknya tindakan atau perilaku seseorang dimulai pada domain pengetahuan terlebih dahulu. Kemudian terbentuklah suatu respon batin (sikap) terhadap objek yang diketahui yang akan diwujudkan melalui tindakan atau perilaku.

Harmanto dan Subroto [16] menyatakan obat modern mempunyai keunggulan tertentu dibandingkan jamu atau obat herbal. Demikian pula jamu dan obat herbal juga mempunyai keunggulan yang tidak dimiliki obat medis modern. Masyarakat yang kritis dan cerdas sudah mulai bisa memilih dan menentukan obat mana yang akan digunakan masyarakat tanpa perlu membanding-bandingkan keunggulan masing-masing obat, 
yang terpenting adalah bahwa keduanya saling melengkapi atau komplementer karena tujuannya sama, yaitu untuk menyembuhkan penyakit.

4. Kesimpulan

Berdasarkan penelitian dapat ditarik kesimpulan bahwa sebagian besar masyarakat Desa Tontulow memiliki tingkat pengetahuan yang cukup mengenai obat tradisional dan obat modern sebanyak 67 responden $(80,7 \%)$ sehingga kemungkinan aplikasi pengetahuan mengenai obat tradisional dan obat modern dalam pengobatan mandiri secara umum dapat diterapkan dengan cukup baik. Sikap masyarakat cenderung positif terhadap obat tradisional dan obat modern. Terdapat hubungan antara pengetahuan dan sikap terhadap tindakan pemilihan obat tradisional dan obat modern (hasil uji korelasi Pearson nilai signifikasi < 0,05).

\section{Referensi}

[1] Depkes RI. 1992. Undang-undang Republik Indonesia No. 23 Tahun 1992 Tentang Kesehatan. Depkes RI: Jakarta.

[2] Pratiwi, P.N., Liza, P., dan Gusti, N. A. I. 2014. Pengaruh Pengetahuan Terhadap PerilakuSwamedikasi Obat Anti-Inflamasi Non-Steroid OralPada Etnis Thionghoa Di Surabaya. Jurnal Farmasi Komunitas Vol. 1, No. 2:Surabaya.

[3] Kartajaya, H. 2011. Self Medication. PT Mark Plus Indonesia: Jakarta Selatan.

[4] Badan Pusat Statistik (BPS). 2016. Survei Sosial Ekonomi Nasional (Susenas) 2014. Badan Pusat Statistik (BPS): Jakarta .

[5] Imron, M. dan Munif, A. 2010. Metodelogi Penelitian Dibidang Kesehatan. CV Sagung Seto: Jakarta.

[6] Supardi, S dan Notosiswoyo, M. 2005. Pengobatan Sendiri Pada Sakit Kepala, Demam, Batuk, dan Pilek Pada Masyarakat Di Desa Ciwalen, Kecamatan Warung Kondang, Kabupaten Cianjur, Jawa Barat. Majalah Ilmu Kefarmasian, Badan Penelitian dan Pengembangan Kesehatan Vol. II, No.3: Jakarta.

[7] Notoatmodjo, S. 1993. Pengantar Pendidikan Kesehatan Dan Ilmu Perilaku Kesehatan. Andi Offset: Yogyakarta.

[8] Arikunto, S. 2010. Prosedur Penelitian. Rineka Cipta: Jakarta.

[9] Wawan, A dan Dewi, M. 2010. Teori Pengukuran Pengetahuan, Sikap, Dan Perilaku Manusia. Nuha Media: Yogyakarta.

[10] Pangastuti, Rinda .M. 2014. Hubungan Pengetahuan dan Sikap Mengenai Obat Tradisional dan Obat Modern Dengan Tindakan Pemilihan Obat Untuk Pengobatan Mandiri di Kalangan Masyarakat Desa Bantir, Kecamatan Candiroto, Kabupaten Temanggung, Jawa Tengah. Skripsi, Fakultas Farmasi, Universitas Sanata Dharma Yogyakarta.

[11] Notoatmodjo, S. 2007.Metode Pendidikan dan Perilaku Kesehatan. Rhineka Cipta: Jakarta.

[12] Departemen Kesehatan RI. 2008. Pedoman penggunaan obat bebas dan obat bebas terbatas. Direktorat Bina Farmasi Komunitas dan Klinik Ditjen Bina Kefarmasian Dan Alat Kesehatan Departemen Kesehatan Republik Indonesia: Jakarta

[13] Azwar, S. 2010. Metode Penelitian. Pustaka Pelajar: Yogyakarta.

[14] Sunaryo. 2004. Psikologi Untuk Keperawatan. EGC: Jakarta.

[15] Cristiana, Eva., 2018. Hubungan Antara Pengetahuan dan Sikap Mengenai Obat Tradisional dan Obat Modern terhadap Tindakan Pemilihan Obat pada Pengobatan Mandiri Di Kalangan Mahasiswa Univaersitas Sanata Dharma Yogyakarta, Skripsi, Universitas Sanata Dharma, Yogyakarta. 
[16] Harmanto., Ning., Subroto, M. 2007. Pilih Jamu dan Herbal Tanpa Efek Samping Cetakan Pertama Elex media: Jakarta. 